\title{
Development of cardiorespiratory fitness standards for working memory using receiver operating curves in 15-year-old adolescents
}

Vinícius Muller Reis Weber ${ }^{1 *}$, Daniel Zanardini Fernandes', Leonardo Alex Volpato', Maria Raquel de Oliveira Bueno ${ }^{1}$, Marcelo Romanzini ${ }^{1}$, Jose Castro-Piñero ${ }^{2,3}$ and Enio Ricardo Vaz Ronque ${ }^{1}$

\begin{abstract}
Background: Working memory performance is associated with better academic achievements in children and adolescents, and it is positively related to CRF. However, what level of cardiorespiratory fitness (CRF) discriminates higher working memory performance is not known. The purpose of this study was to identify CRF thresholds linked to working memory in adolescents.

Methods: Data of 141 adolescents (53.2\% girls) were collected (14.9 years) from a cross-sectional study during the year 2019. CRF was assessed by the 20-m shuttle run test, and maximal oxygen uptake was calculated using the Mahar's equation. Working memory was evaluated by the Corsi blocks test and performance was classified by percentiles. Receiver operating characteristic (ROC) curve analysis was used to identify CRF thresholds.

Results: The ROC analysis indicated that CRF could be used to discriminate working memory in adolescents. CRF thresholds of $\geq 45.03 \mathrm{ml} . \mathrm{kg}^{-1}$. $\mathrm{min}^{-1}$ for boys and $\geq 36.63 \mathrm{ml} . \mathrm{kg}^{-1} \cdot \mathrm{min}^{-1}$ for girls were found to be indicative of "normal" working memory performance.
\end{abstract}

Conclusions: CRF could discriminate low and normal working memory performance in 14-16-year-old adolescents. These thresholds could allow for earlier identification and intervention of low working memory performance using CRF.

Keywords: Executive functions, Cognitive Control, Physical Fitness, Development

\section{Background}

Cardiorespiratory fitness (CRF) and physical activity (PA) have shown positive effects on young people's cognition [1]. Several systematic reviews have suggested that CRF and PA promote benefits in academic $[2,3]$ and cognitive performance $[1,3,4]$ of children and adolescents. In this way, PA has the potential to improve or

\footnotetext{
* Correspondence: viniciusweber1994@gmail.com

'Laboratory of Physical Activity and Health, Center of Physical Education and Sports, Londrina State University - UEL, Londrina, Paraná, Brazil

Full list of author information is available at the end of the article
}

maintain CRF, which in turn can affect brain plasticity [5], leading to improvements in both academic performance and executive functions [6].

Well-developed executive functions are necessary requirements for good academic performance [7]. Among executive functions, working memory stands out, which is a highly important function in the learning and academic performance of children and adolescents [8]. Working memory is responsible for monitoring and coding the information received in order to review and replace information that is no longer relevant due to new

(C) The Author(s). 2021 Open Access This article is licensed under a Creative Commons Attribution 4.0 International License, which permits use, sharing, adaptation, distribution and reproduction in any medium or format, as long as you give appropriate credit to the original author(s) and the source, provide a link to the Creative Commons licence, and indicate if changes were made. The images or other third party material in this article are included in the article's Creative Commons licence, unless indicated otherwise in a credit line to the material. If material is not included in the article's Creative Commons licence and your intended use is not permitted by statutory regulation or exceeds the permitted use, you will need to obtain permission directly from the copyright holder. To view a copy of this licence, visit http://creativecommons.org/licenses/by/4.0/. The Creative Commons Public Domain Dedication waiver (http://creativecommons.org/publicdomain/zero/1.0/) applies to the data made available in this article, unless otherwise stated in a credit line to the data. 
and more useful information [7]. Moreover, for the formation of long-term memory, necessary for the learning process, the information must firstly be encoded as working memory; the construction of new concepts is a process of joining different items together, and these items were firstly kept in mind by the working memory process [9].

Working memory has been associated with CRF $[10,11]$ in children and adolescents, and it has been suggested that PA promotes improvements in physical fitness and improvements in brain structures that support executive functions and memory $[1,11]$. Bruijn et al. [11], found that among executive functions analyzed, visuospatial working memory mediated associations between academic achievements and physical fitness. Hansen et al. [12] observed that CRF had significant quadratic association with academic performance (spelling and mathematics), indicating that 22 to 27 PACER laps were key to significant increases in academic performance of children.

It is known that CRF is used as an important discriminator for health factors in young people [13, 14]. Studies have used CRF levels to discriminate metabolic syndrome [15] and cardiovascular health [16] in adolescents. In addition, many studies have demonstrated the importance of CRF for executive functions in children. These studies have created groups of high and low maximal oxygen uptake $\left(\mathrm{VO}_{2 \max }\right)$,in children by the percentile, and compared these groups for performance in cognitive functions [17-20]; and most of these studies excluded individuals classified in middle percentiles. However, little is known about how much CRF is necessary to be classified with good working memory in adolescence, since most studies have been carried out with children, and information for adolescents is scarce [21].

Furthermore, working memory performance increases over the years, and it increases with childhood maturation; in this sense, adolescents are capable of retaining more information than children [9]. In addition, the $\mathrm{VO}_{2 \max }$ value necessary to stimulate the working memory performance in adolescents is not yet clear.

In this case, a specific threshold could provide the ideal cutoff for a better performance in working memory for adolescents. Therefore, the objective of the present study was to create cutoff CRF points in order to discriminate the working memory performance using receiver operating characteristic (ROC) analysis in adolescents.

\section{Methods}

\section{Sample and study design}

This was a cross-sectional study involving students from public schools of Londrina-PR, Brazil. The sample was composed of 141 adolescents (75 girls), aged 14.9 years and enrolled in secondary education. Adolescents who did not return the consent form signed by parents/ guardians and declared withdrawal during or after data collection were excluded from the study.

The data collection process included obtaining anthropometric measurements, CRF, and working memory. Measurements were performed on two days on the school settings. Working memory and CRF tests were applied on different days to avoid possible interferences. Data were collected during the year 2019.

\section{Anthropometric measurements}

Body mass was measured using portable digital scale, with precision of $0.1 \mathrm{~kg}$ (Seca, Hamburg, Germany) and height with portable stadiometer, with precision of $0.1 \mathrm{~cm}$ (Harpenden Holtain Ltd, Crymych, Dyfed, UK). From this, Body Mass Index (BMI) was estimated (kg/ $\mathrm{m}^{2}$ ). Sum of skinfolds was collected through subscapular and tricipital skinfold thickness, which were measured using scientific adipometer (Lange, Cambridge Scientific Instruments, Cambridge, MD) and performed by experienced evaluator in accordance to techniques stablished by Harrison et al. [22]. The absolute technical error was $0.4 \mathrm{~cm}$ for height and $1.3 \mathrm{~mm}$ for tricipital and $0.96 \mathrm{~mm}$ for subscapular skinfolds.

\section{Cardiorespiratory Fitness}

CRF was evaluated by the 20-m shuttle-run test. This test was conducted on a sports court and the criteria for conduction and completing the test followed procedures described by Léger et al. [23]. The test started at velocity of $8.5 \mathrm{~km} / \mathrm{h}$ and had increment of $0.5 \mathrm{~km} / \mathrm{h}$ every minute. The end of the test was determined by voluntary exhaustion or failure to maintain the velocity determined by each stage in three consecutive signals. $\mathrm{VO}_{2 \max }$ was calculated in $\mathrm{ml} \cdot \mathrm{kg}^{-1} \cdot \mathrm{min}^{-1}$, using the quadratic equation suggested by Mahar et al. [24], and recommended by the FITNESSGRAM.

\section{Working memory}

To verify the working memory, the Corsi block-tapping task (CB) was used. The Corsi Block Test is widely used both in clinical practice and research, and specifically evaluates short-term visuospatial working memory [25]. Originally developed by Corsi [26], this test involves simple measurements that can be quickly and easily administered, requiring the subject to maintain the information sequence [25]. This test have good reliability for 15 -year-old adolescents $(r=0.79)$ and moderate validity $(r=0.66)$ [27].

According to the normative standardization of the Corsi block test, $20 \%$ of individuals with the worst test results can be considered as "low performance" [25]. In addition, subjects classified with $0.6 \mathrm{z}$-score below the group that they belong are identified with low 
neuropsychological ability. In the same way, if the test is easy, $80 \%$ could be classified as middle score [28].

The test consists in memorizing a sequence in which cubes flash on a computer screen. The test starts with two cubes flashing in the middle of nine cubes disposed on the screen (encoding phase), each cube flashing for $250 \mathrm{~ms}$. In sequence, the adolescent tries to reproduce the sequence in the same order (forward condition) in which cubes appears (recall phase), which does not have time to finish. After the response, the adolescent received feedback (1000ms) and start a new encoding phase (Fig. 1). The order in which cubes flash increases progressively until maximum limit is reached. The test was interrupted when the participant misses the sequence order twice at the same level. Block Span (CB extension) and total score (block span x number of correct responses until the test was interrupted) were adopted as performance indicators. Adolescents had one execution in the test for adaptation.
For classification into normal and low performance, 20 percentiles as described by Kessels et al. [25] was used. Adolescents who obtained the $20 \%$ lowest scores were classified as low performance. Classification was performed according to sex.

\section{Statistical analyses}

Median and interquartile ranges were used for sample description. Mann Whitney U was adopted for comparison of variables between groups. ROC analysis was used to discriminate adolescents with normal performance from those with low performance for working memory with $\mathrm{VO}_{2 \max }$. For ROC analysis, the area under the curve (AUC) was used for analysis of the accuracy of cutoff points. Better ROC analysis results are found for sensitivity and specificity close to 100 , in this case indicating high positive cases and low false-positive cases.

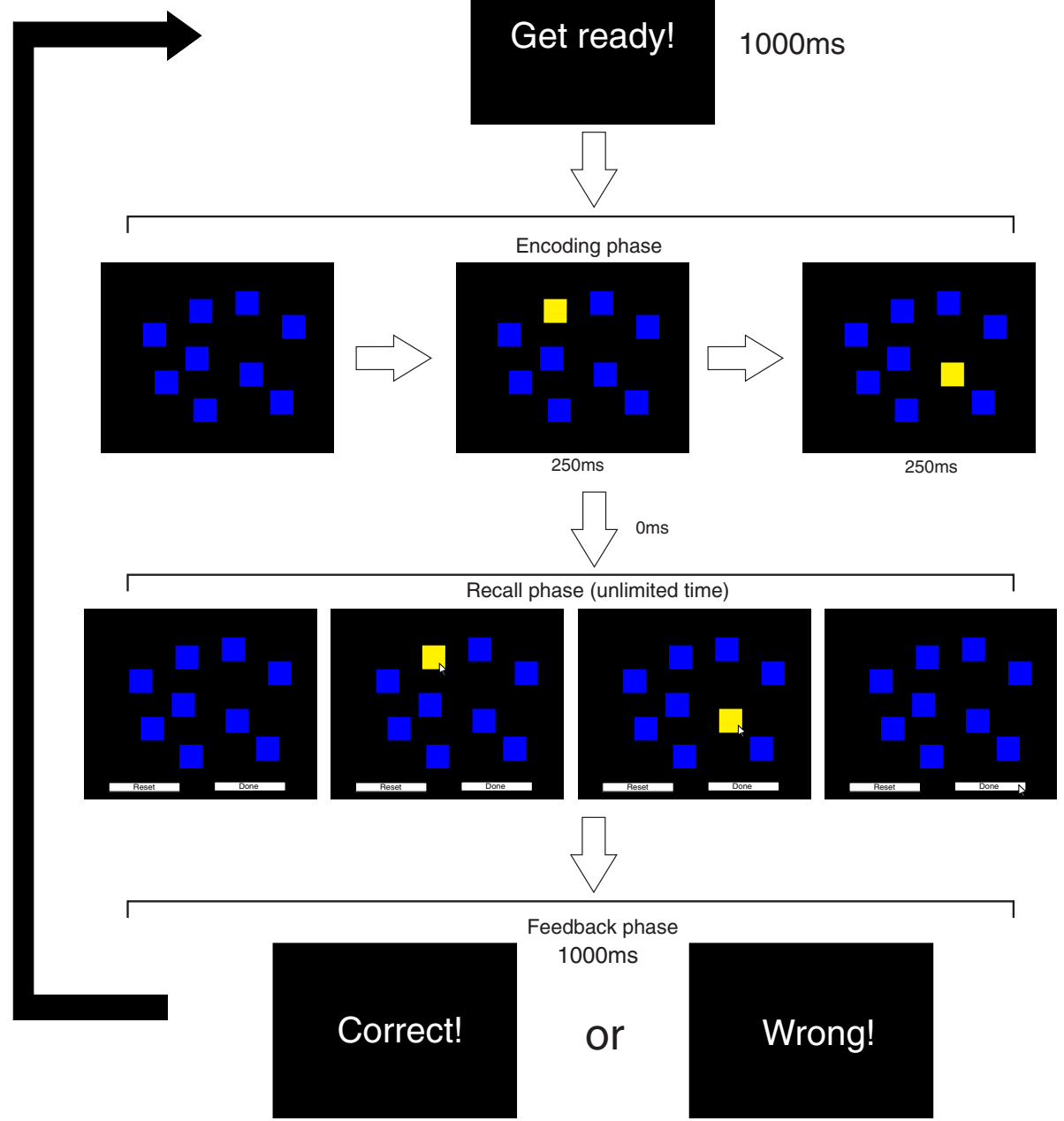

Fig. 1 Corsi block task 
After identifying cutoff values, two groups were created, high CRF (Boys $\geq 45.03$; Girls $\geq 36.63$ ) and Low CRF (Boys < 45.03; Girls < 36.63) in order to compare groups; the comparison was performed by the generalized estimating equation and values were expressed in estimated means and confidence intervals. Analyses were controlled by sex and $\Sigma$ of tricipital and subscapular skinfolds. Significance was set at $5 \%$. All analyses were conducted using statistical software SPSS version 26.0 and MedCalc version 19.1.2.

\section{Results}

Table 1 shows the sample characterization between subjects classified as normal or low performance and stratified by sex. Results demonstrate significant differences for $\mathrm{VO}_{2 \max }$ (Girls: $P=0.023$; Boys: $P=0.037$ ) and for working memory variables (Block Span and Total Score, $P<0.001)$. Higher CRF values and working memory performance were found for adolescents classified as normal cognitive performance.

Figure 2 presents the ROC Curves analysis for $\mathrm{VO}_{2 \max }$ and working memory classification (low or normal). In both sexes, $\mathrm{VO}_{2 \max }$ was able to discriminate subjects with low and normal working memory ability $(P<0.05)$. For boys, the cutoff value to be classified as "normal" was $\geq 45.03 \mathrm{ml} \cdot \mathrm{kg}^{-1} \cdot \mathrm{min}^{-1}$ (Sensitivity 47.1; Specificity 91.8); $\mathrm{VO}_{2 \max }$ was able to discriminate cases with accuracy of $67.1 \%$ (AUC $=0.671$; CI95 \%: 0.544-0.782). For girls, the value was $\geq 36.63 \mathrm{ml} . \mathrm{kg}^{-1} \cdot \mathrm{min}^{-1}$ (Sensitivity 72; Specificity 70) and discriminate normal or low performance subjects with accuracy of $66.2 \%$ (AUC $=0.662$; CI95 \%: 0.543-0.767).

Comparisons between high and low CRF are shown in Table 2. Significant differences were found for $\mathrm{VO}_{2 \max }$ and total score in Corsi Blocks test for all boys, demonstrating that boys classified as high CRF presented higher working memory values if compared to low CRF individuals (df:16.22; $P=0.001)$.

\section{Discussion}

The main objective of the present study was to verify the level of $\mathrm{CRF}\left(\mathrm{VO}_{2 \max }\right)$ that discriminates working memory in adolescents. Results showed that boys need minimum of $45.03 \mathrm{ml} . \mathrm{kg}^{-1} \cdot \mathrm{min}^{-1}$ and girls 36.63 $\mathrm{ml} . \mathrm{kg}^{-1} \cdot \mathrm{min}^{-1}$ to be classified as "normal". Additionally, $\mathrm{VO}_{2 \max }$ thresholds presented significant differences for working memory, which demonstrated higher working memory values for group with high CRF.

Comparing CRF groups with academic achievement, adolescents classified in the Health Fitness Zone (HFZ), FITN ESSGRAM, presented higher academic grades [1, 29]. When the relationship between CRF and academic achievement in children was evaluated, Hansen et al. [12] found non-linear relationship, with increases in academic performance occurring up to 22 laps $\left(\sim 47.5 \mathrm{ml} . \mathrm{kg}^{-1} . \mathrm{min}^{-1}\right)$ for spelling and $27\left(\sim 49.7 \mathrm{ml} . \mathrm{kg}^{-1} \cdot \mathrm{min}^{-1}\right)$ laps for math scores, after that, performance reached a plateau.

The relationship between CRF (pacer laps) and working memory performance, in children, presented significance, analyzing the reaction time $(\mathrm{r}=-0.13)$, and working memory accuracy $(r=0.14)$ [30]. Analyzing relationships longitudinally and controlling other variables (grade, sex, maternal education, BMI), CRF can explain by $7.5 \%$ the working memory accuracy [31]. In addition, improvements in CRF are associated with improvements in the cognitive control of the working memory of preadolescents [32].

According to results of the present study, higher CRF values, classified by the created threshold, indicated better working memory for boys. However, for girls, this result did not show significance; a possible justification to this result is that the maturation of the cognitive control takes longer for boys than for girls [33]. Thus, girls probably suffer less CRF impact

Table 1 Characterization of the sample stratified by sexes and working memory performance

\begin{tabular}{|c|c|c|c|c|c|c|}
\hline & \multicolumn{2}{|l|}{ Girls $(n=75)$} & \multirow[b]{2}{*}{$P$} & \multicolumn{2}{|l|}{ Boys $(n=66)$} & \multirow[b]{2}{*}{$P$} \\
\hline & Low & Normal & & Low & Normal & \\
\hline Age (years) & $15.01(14.54-15.19)$ & $14.96(14.54-15.42)$ & 0.822 & $14.82(14.09-15.99)$ & $15.05(14.55-15.47)$ & 0.587 \\
\hline Body Mass (Kg) & 55.9 (53.0-67.65) & 55.25 (50.92-65.95) & 0.455 & $64.80(53.15-82.35)$ & $59.6(54.75-69.8)$ & 0.232 \\
\hline Height (cm) & 161.5 (156.85-169.55) & 163.55 (158.12-168.52) & 0.728 & $172.4(164.5-176.15)$ & $171.7(167.7-175.65)$ & 0.764 \\
\hline BMI $\left(\mathrm{Kg} / \mathrm{m}^{2}\right)$ & $21.85(20.29-25.56)$ & 21.15 (19.09-24.97) & 0.351 & $22.13(17.55-27.47)$ & 20.35 (18.20-22.70) & 0.210 \\
\hline$\Sigma$ skinfold (mm) & $42(32.50-59.5)$ & $39.75(31.0-54.5)$ & 0.441 & $37.0(18.25-51.0)$ & $26.0(19.0-37.75)$ & 0.278 \\
\hline $\mathrm{Vo}_{2 \max }\left(\mathrm{ml} \cdot \mathrm{kg}^{-1} \cdot \mathrm{min}^{-1}\right)$ & 35.71 (33.19-39.60) & 40.01 (34.19-42.82) & 0.023 & $47.39(39.38-52.52)$ & 50.09 (46.79-54.28) & 0.037 \\
\hline $\begin{array}{l}\text { Corsi Blocks } \\
\text { Block Span } \\
\text { Total Score }\end{array}$ & $\begin{array}{l}5(5-5) \\
35(27.5-35)\end{array}$ & $\begin{array}{l}6(5-7) \\
54.0(40-70)\end{array}$ & $\begin{array}{l}<0.001 \\
<0.001\end{array}$ & $\begin{array}{l}5(5-5) \\
35(30-35)\end{array}$ & $\begin{array}{l}6(6-7) \\
54(45-70)\end{array}$ & $\begin{array}{l}<0.001 \\
<0.001\end{array}$ \\
\hline
\end{tabular}



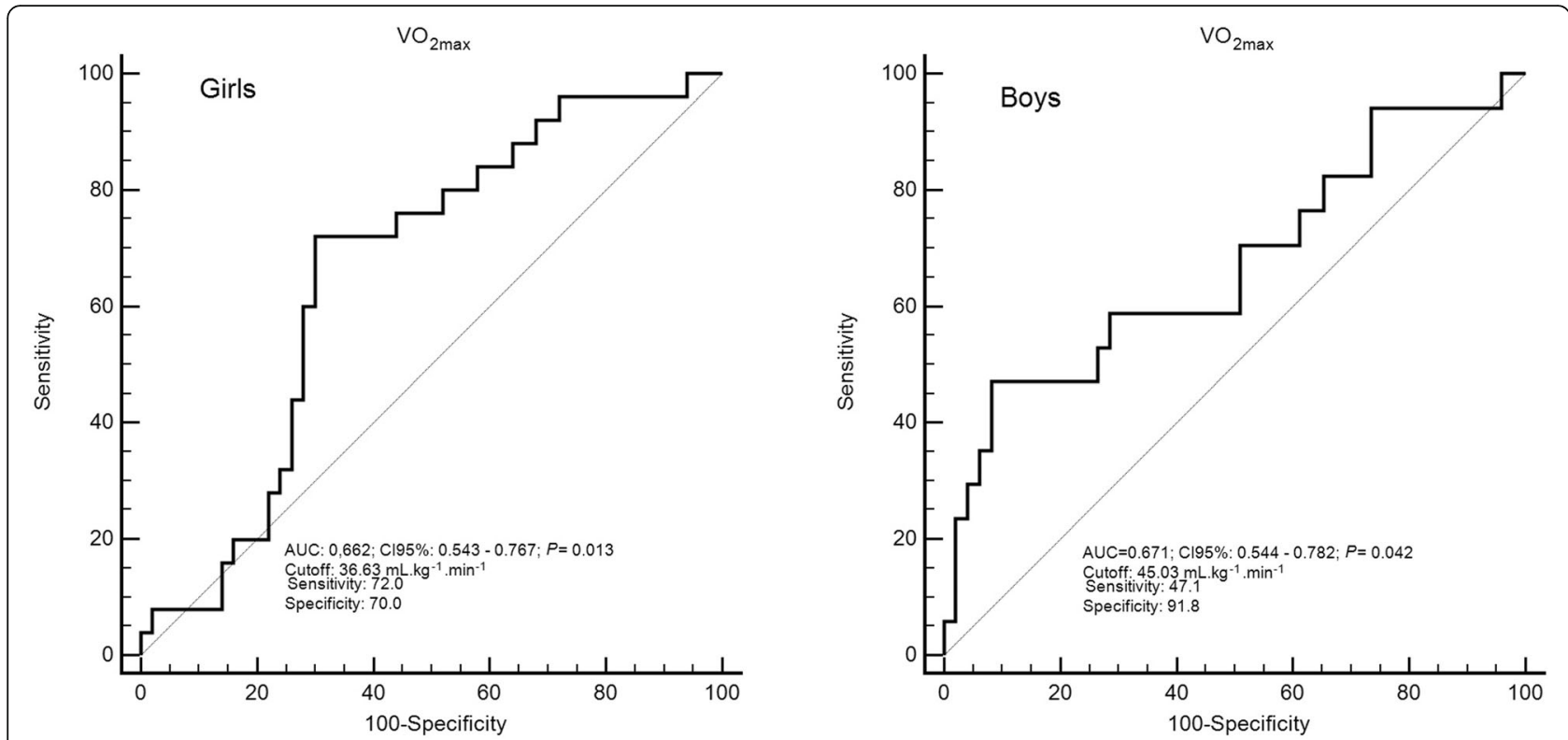

Fig. 2 Receiver operating characteristic curvesNote: AUC: area under the curve

on cerebral structures. At the age of 15 years, girls have some advantages (cortical thickness) in brain regions [34], responsible for the working memory. Haapala et al. [35] found significant positive relationship for physical activity and academic achievement for boys and not for girls, suggesting differences between boys and girls. These differences, mainly related to cognitive functions, are not well understood, and further studies are needed.

The threshold values for $\mathrm{VO}_{2 \max }$ to discriminate low and normal working memory in the present study are similar to those used by FITNESSGRAM ${ }^{\circ}$, developed by Welk et al. [15], which determined the presence of metabolic syndrome through $\mathrm{VO}_{2 \max }$ measured by submaximal treadmill test. For boys, the HFZ value was $\geq 43.6$ $\mathrm{ml} . \mathrm{kg}^{-1} \cdot \mathrm{min}^{-1}$, a difference of $1.7 \mathrm{ml} . \mathrm{kg}^{-1} \cdot \mathrm{min}^{-1}$ from the present study; for girls, the HFZ value was $\geq 39.1$ $\mathrm{ml} . \mathrm{kg}^{-1} \cdot \mathrm{min}^{-1}$, showing difference of 2.47 $\mathrm{ml} . \mathrm{kg}^{-1} \cdot \mathrm{min}^{-1}$.
Ruiz et al. [16] established CRF cutoff points to determine the cardiovascular health profile of adolescents, finding values of $43.8 \mathrm{ml} \cdot \mathrm{kg}^{-1} \cdot \mathrm{min}^{-1}$ for boys and 34.6 $\mathrm{ml} . \mathrm{kg}^{-1} \cdot \mathrm{min}^{-1}$ for girls. Likewise, these values are similar to those found in the present study, demonstrating that cardiovascular health and mental functions are affected in similar CRF intensities in adolescents.

The low sensitivity and high specificity found for boys can be explained by the number of boys with high CRF in this sample. Low-performance adolescents showed median $\mathrm{VO}_{2 \max }$ value of $47.39 \mathrm{ml} . \mathrm{kg}^{-1} \cdot \mathrm{min}^{-1}$ (39.3852.52). Using the classification proposed by an international normative [36], the low-performance group had subjects in the 50th percentile but some individuals could reach the 90th percentile. On the other hand, the high specificity of created cutoff points $(91.8 \%)$ implies that individuals with low CRF are more likely of being classified as low performance. This pattern was not found for girls, in which the similar sensitivity and

Table 2 - Comparison of cardiorespiratory fitness groups for $\mathrm{VO}_{2 \max }$ and working memory performance in adolescents

\begin{tabular}{|c|c|c|c|c|c|}
\hline & $\mathrm{N}$ & $\begin{array}{l}\mathrm{VO}_{2 \max }\left(\mathrm{ml} \cdot \mathrm{kg}^{-1} \cdot \mathrm{min}^{-1}\right) \\
\text { Estimated means }(95 \% \mathrm{Cl})\end{array}$ & $P$ & $\begin{array}{l}\text { Total Score } \\
\text { Estimated means }(95 \% \mathrm{Cl})\end{array}$ & $P$ \\
\hline $\begin{array}{l}\text { All } \\
\text { Low CRF } \\
\text { High CRF }\end{array}$ & $\begin{array}{l}45 \\
96\end{array}$ & $\begin{array}{l}34.3(33.0-35.7) \\
47.1(46.0-48.3)\end{array}$ & $<0.001$ & $\begin{array}{l}43.7(38.7-49.4) \\
53.2(49.5-57.35)\end{array}$ & 0.005 \\
\hline $\begin{array}{l}\text { Boys } \\
\text { Low CRF } \\
\text { High CRF }\end{array}$ & $\begin{array}{l}12 \\
54\end{array}$ & $\begin{array}{l}39.5(37.5-41.5) \\
51.1(50.2-52.1)\end{array}$ & $<0.001$ & $\begin{array}{l}39.5(32.5-47.9) \\
55.7(50.6-61.3)\end{array}$ & 0.001 \\
\hline $\begin{array}{l}\text { Girls } \\
\text { Low CRF } \\
\text { High CRF }\end{array}$ & $\begin{array}{l}33 \\
42\end{array}$ & $\begin{array}{l}32.4(31.2-33.6) \\
41.9(41.0-42.9)\end{array}$ & $<0.001$ & $\begin{array}{l}45.3(39.1-52.4) \\
50.1(44.7-56.1)\end{array}$ & 0.280 \\
\hline
\end{tabular}

CRF Cardiorespiratory fitness; $95 \% \mathrm{Cl}$ Confidence interval of $95 \%$; Significant values for $P<0.05$ 
specificity could be justified by the homogeneous $\mathrm{VO}_{2 \max }$ distribution.

Another fact to be highlighted is the changes that CRF can cause in cerebral morphology, and these changes are related to working memory performance. It is noteworthy that well-developed prefrontal cortex [37, 38] and greater hippocampal volume [39] are associated with better working memory. In addition, children with higher CRF have greater hippocampal volume [39, 40]. The relationship between CRF and relational memory is mediated by the hippocampal volume [39]. Better working memory is related to joining different concepts to solve a problem that may require a combination of different strategies, and more complex tasks require the joining of more parts [9].

Neuroelectric indexes are also related to working memory, and evidence suggests that higher P3 amplitude, an event related to the neuronal activity and linked to attentional processing, is associated with better working memory $[6,41]$. Comparing to individuals with high and low CRF by Event-Related Potentials, the results demonstrated better P3 indexes for children with high CRF [10, 42]; and higher functional connectivity [20]. The increase in neuronal connectivity, resulting from neuronal density and myelination, mainly in areas of the brain responsible for the working memory, could lead to better working memory performance [43].

Further studies could assess the possible cause and effect relationship between CRF and working memory performance. Further studies should also evaluate CRF by aerobic training and its relationship with working memory; therefore, more randomized controlled trials are necessary to elucidate this relationship. Last but not least, new studies are required to evaluate sex differences associated to CRF impacts on cognitive performance.

This study has some limitations such as the relatively small sample size and the creation of thresholds only for adolescents aged 14-16 years. Another limitation was not using academic achievements for the development of thresholds to compare working memory. However, a strong point is the creation of thresholds for working memory in adolescents, which is possibly one of the first studies with this objective. In addition, this study used sample composed of adolescents, and many studies used children in the second infancy [21].

\section{Conclusions}

In summary, $\mathrm{VO}_{2 \max }$ can be used to discriminate adolescents classified as low or normal working memory performance. In this sense, these results can complement normative health data or be useful in school programs, since working memory can improve academic performance.

\section{Abbreviations}

CRF: Cardiorespiratory fitness; PA: Physical activity; $V_{2 m a x}$ : Maximal oxygen uptake; ROC: Receiver operating characteristic; BMI: Body mass index; AUC: Area under curve; HFZ: Health fitness zone

\section{Acknowledgements}

The authors would like to thank the Conselho Nacional de Desenvolvimento Científico e Tecnológico (CNPq) for the research productivity grant (ERVR) and the Coordenação de Aperfeiçoamento de Pessoal de Nível Superior (CAPES) for the PhD/MSc scholarship (VMRW, DZF, MROB).

\section{Authors' contributions}

VMRW: Conception and Design, methodology, data collection, analysis and interpretation of data, drafting the article, final approval. DZF: Conception and Design; analysis of data, data collection, drafting the article, final approval. LAV: Methodology, data collection, final approval. MROB: Methodology, data collection, final approval. MR: Revising it critically, supervision, final approval. JC: Revising it critically, analysis and interpretation, final approval. ERVR: Conception and Design, methodology, drafting the article, supervision, final approval.

Funding

There is no funding source.

Availability of data and materials

The datasets used and/or analyzed during the current study are available from the corresponding author on reasonable request.

\section{Declarations}

Ethical approval and consent to participate

The local ethics committee (Ethics Committee in Research with Human Beings of the State University of Londrina) approved all the procedures of the present study according to norms of resolution No. 466/2012 of the National Health Council on research involving human beings under protocol No. 3.679.195. Parents had to sign the consent form and adolescents the assent form.

\section{Consent for publication}

Not applicable.

\section{Competing interests}

The authors declares that they have no competing interests.

\section{Author details}

${ }^{1}$ Laboratory of Physical Activity and Health, Center of Physical Education and Sports, Londrina State University - UEL, Londrina, Paraná, Brazil. ${ }^{2}$ GALENO Research Group Department of Physical Education, School of Education, University of Cadiz, Puerto Real, Spain. ${ }^{3}$ Biomedical Research and Innovation Institute of Cadiz (INiBICA) Research Unit, 11009 Cadiz, Spain.

Received: 21 September 2020 Accepted: 20 April 2021

Published online: 29 April 2021

\section{References}

1. Donnelly JE, Hillman CH, Castelli D, Etnier JL, Lee S, Tomporowski P, Lambourne K, Szabo-Reed AN. Physical Activity, Fitness, Cognitive Function, and Academic Achievement in Children. Med Sci Sport Exerc. 2016;48:1197222.

2. Howie EK, Pate RR. Physical activity and academic achievement in children: A historical perspective. J Sport Heal Sci. 2012;1:160-9.

3. de Greeff JW, Bosker RJ, Oosterlaan J, Visscher C, Hartman E. Effects of physical activity on executive functions, attention and academic performance in preadolescent children: a meta-analysis. J Sci Med Sport. 2018;21:501-7.

4. Fedewa A. The Effects of Physical Activity and Physical Fitness on Children's Achievement and Cognitive Outcomes: A Meta-Analysis. Res Q Exerc Sport. 2011. https://doi.org/10.5641/027013611×13275191444107.

5. Hillman $\mathrm{CH}$, Erickson Kl, Kramer AF. Be smart, exercise your heart: exercise effects on brain and cognition.(SCIENCE AND SOCIETY)(Report). Nat Rev Neurosci. 2008;9:58. 
6. Chaddock L, Pontifex MB, Hillman CH, Kramer AF. A review of the relation of aerobic fitness and physical activity to brain structure and function in children. J Int Neuropsychol Soc. 2011;17:975-85.

7. Best JR, Miller PH, Naglieri JA. Relations between executive function and academic achievement from ages 5 to 17 in a large, representative national sample. Learn Individ Differ. 2011;21:327-36.

8. Van der Niet AG, Hartman E, Smith J, Visscher C. Modeling relationships between physical fitness, executive functioning, and academic achievement in primary school children. Psychol Sport Exerc. 2014;15:319-25.

9. Cowan N. Working Memory Underpins Cognitive Development, Learning, and Education. Educ Psychol Rev. 2014;26:197-223.

10. Mora-Gonzalez J, Esteban-Cornejo I, Cadenas-Sanchez C, Migueles JH, Rodriguez-Ayllon M, Molina-García P, Hillman CH, Catena A, Pontifex MB, Ortega FB. Fitness, physical activity, working memory, and neuroelectric activity in children with overweight/obesity. Scand J Med Sci Sport. 2019;29: 1352-63.

11. de Bruijn AGM, Hartman E, Kostons D, Visscher C, Bosker RJ. Exploring the relations among physical fitness, executive functioning, and low academic achievement. J Exp Child Psychol. 2018;167:204-21.

12. Hansen DM, Herrmann SD, Lambourne K, Lee J, Donnelly JE. Linear/ nonlinear relations of activity and fitness with children's academic achievement. Med Sci Sports Exerc. 2014;46:2279-85.

13. Ruiz JR, Cavero-Redondo I, Ortega FB, Welk GJ, Andersen LB, MartinezVizcaino V. Cardiorespiratory fitness cut points to avoid cardiovascular disease risk in children and adolescents; What level of fitness should raise a red flag? A systematic review and meta-analysis. Br I Sports Med. 2016;50: 1451-8.

14. Lang JJ, Tremblay MS, Ortega FB, Ruiz JR, Tomkinson GR. Review of criterion-referenced standards for cardiorespiratory fitness: what percentage of 1142026 international children and youth are apparently healthy? Br J Sports Med. 2019;53:953-8.

15. Welk GJ, Laurson KR, Eisenmann JC, Cureton KJ. Development of youth aerobic-capacity standards using receiver operating characteristic curves. Am J Prev Med. 2011;41:93-9.

16. Ruiz JR, Huybrechts I, Cuenca-García M, et al. Cardiorespiratory fitness and ideal cardiovascular health in European adolescents. Heart. 2015;101:766-73.

17. Chaddock L, Hillman CH, Buck SM, Cohen NJ. Aerobic fitness and executive control of relational memory in preadolescent children. Med Sci Sports Exerc. 2011;43:344-9.

18. Raine LB, Lee HK, Saliba BJ, Chaddock-Heyman L, Hillman CH, Kramer AF. The influence of childhood aerobic fitness on learning and memory. PLoS One. 2013. https://doi.org/10.1371/journal.pone.0072666.

19. Chaddock L, Hillman CH, Pontifex MB, Johnson CR, Raine LB, Kramer AF. Childhood aerobic fitness predicts cognitive performance one year later. J Sports Sci. 2012;30:421-30.

20. Kamijo K, Takeda Y, Takai Y, Haramura M. The relationship between childhood aerobic fitness and brain functional connectivity. Neurosci Lett. 2016;632:119-23

21. Valkenborghs SR, Noetel M, Hillman CH, Nilsson M, Smith JJ, Ortega FB, Lubans DR. The impact of physical activity on brain structure and function in youth: A systematic review. Pediatrics. 2019. https://doi.org/10.1542/ peds.2018-4032.

22. Harrison GG, Buskirk ER, Carter LJE, Johston FE, Lohman TG, Pollock ML et al. Skinfold thicknesses and measurement technique. In: Lohman TG, Roche AF, Martorell R, editors. Anthr. Stand. Ref. Man. Champaign: Human Kinetics Books; 1988. pp. 55-70.

23. Léger LA, Mercier D, Gadoury C, Lambert J. The multistage 20 metre shuttle run test for aerobic fitness. J Sports Sci. 1988;6:93-101.

24. Mahar MT, Guerieri AM, Hanna MS, Kemble CD. Estimation of aerobic fitness from 20-m multistage shuttle run test performance. Am J Prev Med. 2011; 41:117-23.

25. Kessels RPC, van Zandvoort MJE, Postma A, Kappelle LJ, de Haan EHF. The Corsi Block-Tapping Task: Standardization and Normative Data. Appl Neuropsychol. 2000;7:252-8.

26. Corsi PM. (1973) Human memory and the medial temporal region of the brain. 34:891.

27. Orsini A. Corsi's Block-Tapping Test: Standardization and Concurrent Validity with WISC—R for Children Aged 11 to 16. Percept Mot Skills. 1994;79:154754.

28. Lezak MD, Howieson DB, Bigler ED, Tranel D. Neuropsychological assessment. 5th ed. New York: Oxford University Press; 2012.
29. Wittberg RA, Northrup KL, Cottrel L. Children's physical fitness and academic performance. Am J Heal Educ. 2009;40:30-6.

30. Scudder MR, Lambourne K, Drollette ES, Herrmann SD, Washburn RA, Donnelly JE, Hillman CH. Aerobic capacity and cognitive control in elementary school-age children. Med Sci Sports Exerc. 2014;46:1025-35.

31. Scudder MR, Drollette ES, Szabo-Reed AN, Lambourne K, Fenton Cl, Donnelly JE, Hillman CH. Tracking the Relationship Between Children's Aerobic Fitness and Cognitive Control. Heal Psychol. 2016;35:967-78.

32. Kamijo K, Pontifex MB, O'Leary KC, Scudder MR, Wu CT, Castelli DM, Hillman $\mathrm{CH}$. The effects of an afterschool physical activity program on working memory in preadolescent children. Dev Sci. 2011;14:1046-58.

33. Vuontela V, Steenari MR, Carlson S, Koivisto J, Fjällberg M, Aronen ET. Audiospatial and visuospatial working memory in 6-13 year old school children. Learn Mem. 2003;10:74-81.

34. Gennatas ED, Avants BB, Wolf DH, Satterthwaite TD, Ruparel K, Ciric R, Hakonarson H, Gur RE, Gur RC. Age-related effects and sex differences in gray matter density, volume, mass, and cortical thickness from childhood to young adulthood. J Neurosci. 2017;37:5065-73.

35. Haapala EA, Lintu N, Väistö J, et al. Longitudinal Associations of Fitness, Motor Competence, and Adiposity with Cognition. Med Sci Sports Exerc. 2019;51:465-71.

36. Tomkinson GR, Lang JJ, Tremblay MS, Dale M, Leblanc AG, Belanger K, Ortega FB, Léger $L$. International normative $20 \mathrm{~m}$ shuttle run values from 1 142026 children and youth representing 50 countries. Br J Sports Med. 2017:51:1545-54.

37. Casey BJ, Giedd JN, Thomas KM. Structural and functional brain development and its relation to cognitive development. Biol Psychol. 2000; 54:241-57.

38. Khan NA, Hillman CH. The Relation of Childhood Physical Activity and Aerobic Fitness to Brain Function and Cognition: A Review. Pediatr Exerc Sci. 2014;26:138-46.

39. Chaddock L, Erickson Kl, Prakash RS, et al. A neuroimaging investigation of the association between aerobic fitness, hippocampal volume, and memory performance in preadolescent children. Brain Res. 2010;1358:172-83.

40. Ortega FB, Campos D, Cadenas-Sanchez C, Altmäe S, Martínez-Zaldívar C, Martín-Matillas M, Catena A, Campoy C. (2017) Physical fitness and shapes of subcortical brain structures in children. Br J Nutr 1-10.

41. Hillman CH, Pontifex MB, Motl RW, O'Leary KC, Johnson CR, Scudder MR, Raine LB, Castelli DM. From ERPs to academics. Dev Cogn Neurosci. 2012;2: 90-8.

42. Hillman $\mathrm{CH}$, Castelli DM, Buck SM. Aerobic fitness and neurocognitive function in healthy preadolescent children. Med Sci Sports Exerc. 2005;37: 1967-74.

43. Bunge SA, Wright SB. Neurodevelopmental changes in working memory and cognitive control. Curr Opin Neurobiol. 2007;17:243-50.

\section{Publisher's Note}

Springer Nature remains neutral with regard to jurisdictional claims in published maps and institutional affiliations.

Ready to submit your research? Choose BMC and benefit from:

- fast, convenient online submission

- thorough peer review by experienced researchers in your field

- rapid publication on acceptance

- support for research data, including large and complex data types

- gold Open Access which fosters wider collaboration and increased citations

- maximum visibility for your research: over $100 \mathrm{M}$ website views per year

At BMC, research is always in progress.

Learn more biomedcentral.com/submissions 